\title{
Present Development in Horticulture
}

\author{
Muhammad Irfan Ashraf ${ }^{1}$, Shoukat Sajad ${ }^{1 *}$ \\ ${ }^{1}$ Department of Horticulture, University of Agriculture, Pakistan
}

Submission: July 20, 2018; Published: July 31, 2018

*Corresponding author: Shoukat Sajad, Institute of Horticulture, University of Agriculture, Faisalabad, Pakistan, Email: imshoukat@outlook.com

Keywords: Horticulture; Plants; Vegetables; Fruits; Medicinal plants; Sprouts; Mushroom; Algae; Olericulture; Viticulture; Amaranthus viridis; Fertilizers; Passifloraceae; Fruit ripening; Feeding activity; Azotobacter

\section{Mini Review}

Horticulture is a branch of agriculture that deals with science, art, and business development of growing plants. It includes all type of plants such as, vegetables, fruits, medicinal plants, sprouts, mushroom, and algae etc., and also non-food crops like ornamental plants, trees, and grass. A horticulturist is a person who applies his knowledge, technology, and skills to grow plants intensively that are used by humans for food and non-food needs. Horticulture involves nine areas of study such as, Arboriculture, Turf management, Floriculture, Landscape horticulture, olericulture, pomology, viticulture, oenology, and postharvest physiology. The Journal of Horticulture is an open access journal that publishes high impact research articles.

Foster et al. [1] studied the effect of different growing environments in modifying first expression of root-stockinduced dwarfing of the scion. An experiment was conducted in which Royal Gala trees were grafted onto the three different vigor clonal root stocks such as M27', 'M9', and 'M793'and grown in three different locations. The growth and detailed architectural measurement were done over first year and repeated for the second year. This work demonstrated that primary axis or sylleptic shoot termination is consistently expressed by M9 and M27 dwarfing rootstock in different growing environments and years. Tus, this study provided new phenotypic information for future studies for elucidating the genetic and physiological bases for apple root-stock induced dwarfing.

Babatunde et al. [2] tried to obtain information on interaction of tillage passes and NPK fertilizers application rates on some growth factors of Amaranthus viridis. The soil treatment of this experiment includes three levels of tillage passes $(0,3$, and 6$)$ that equivalent to the soil density $1.7,1.3$, and $1.5 \mathrm{~g} / \mathrm{cm}^{3}$ respectively and four levels of NPK fertilizers $(0,100,150$, and $200 \mathrm{~kg} / \mathrm{ha})$. This experiment was continued for three replications in randomized designed plots. This experimental result summarized that the effects of interactions between tillage and fertilizers rates were observed on stem girth, fresh weight, plant height, root length, and percent of $\mathrm{N}, \mathrm{P}$, and $\mathrm{K}$ uptake. The increase in plant height and improved uptake of phosphorous were observed at T2F2 (6 passes and $150 \mathrm{~kg} / \mathrm{ha}$ ). Thus, they concluded that T2F2 (6 passes and $150 \mathrm{~kg} / \mathrm{ha}$ ) NPK fertilizer application could be more suitable for the optimum yield for Amaranthus viridis on sandy clay soil.

The passion fruit belongs to Passifloraceae family that is native of southern Brazil through Paraguay to northern Argentina. Matheri et al. [3] tried to study the phenotypic variations existing between Purple and Brazil varieties, as well as their hybrids that are developed by KALRO. The phenotypic variations were observed by applying principle component technique and cluster analysis statistical tools of Minitab 17.0 software to discriminate the accessions based on seven quantitative morpho-agronomic traits targeted with replication per plant and variety. The dendrogram and scatter plot clustered indicates the phenotypic relatedness within the varieties. Thus, this study affords the current body of knowledge on passion fruit breeding.

Zhang et al. [4] studied the cold tolerance of Kentucky blue grass at the genomic level. For this they sequenced and analyzed the Kentucky blue grass transcriptomes under cold treatment and control treatment by RNA-seq and de novo assembly. At the same time they also aimed to identify more transcription factors associated to cold tolerance. In this study, nearly 3,896 unigenes were identified between control and cold treated plants and several transcriptional factors were identified as differentially expressed genes. Thus, this study provided valuable resource for the studies on the transcriptional regulation of cold tolerance.

Yuan et al. [5] aimed to study the role of PuADF in fruit ripening. Expression of ADF gene, named PuADF, which is down-regulated during fruit ripening. The screening of cDNA 
library from 'Nanguo' pear fruit using PuADF as bait identified two proteins that interacted with PuAS and PuDAD1that are associated with program cell death. This expression PuAS and PuDAD1 was affected by ethylene. Thus, they concluded that PuADF is involved in ethylene-mediated fruit ripening and interact with PuAS and PuDAD1, which in turn are involved in fruit ripening.

The Japanese beetle (Popillia japonica) one of the mostwide spread and destructive insect pest which damages various fruits, field, and garden crops. Management of these beetles with bacillus thuringiensis galleriae is possible but its activity is not long lasting. Maier et al. [6], hypothesized the management of Japanese beetle with Kaolin clay. Its mechanism includes repellency, impairment or disruption of ovi position and feeding activity. The abrasive mineral present in Kaolin clay promotes the cuticle disruption and digestive system obstruction. Various field tests with Kaolin clay in different application rates effectively minimized the feeding damage caused by Japanese beetles and no side-effects were recorded on several fruit weight. Thus, Kaolin clay is a good alternative for the management of Japanese beetle.

Aryal et al. [7] conceptualized integrated nutrient management technology for better fruit yield in Chilly. This experiment was laid out in completely randomized block design, that include three replication and nine treatments that includes N1A1, N1A2, N1A3, N2A1, N2A2, N2A3, N3A1, N3A2, and N3A3, which was conducted in IAAS farm, Lamjung. The combination of nitrogen and Azotobacter in indicated by $\mathrm{N}$ and A respectively, in which 1,2,3 indicates controls and 3 and 4 indicate $50 \mathrm{~kg} / \mathrm{ha}$ and $100 \mathrm{~kg} / \mathrm{ha}$, respectively. From the results, it is clear that soil treated with N3A3 which consists of $100 \mathrm{~kg} / \mathrm{ha}$ nitrogen and seedling inoculation of Azotobacter is the best combination for good yield of chilly.

\section{References}

1. Foster TM, van Hooijdonk BM, Friend AP, Seleznyova AN, McLachlan ARG (2016) Apple Rootstock-Induced Dwarfng is Strongly Influenced by Growing Environment. J Hortic 3.

2. Babatunde KM, Adekanmbi OA, Adeyolanu AS, Salau MA (2016) Effects of Varying Tillage Passes and 15-15-15 NPK Fertilizer on Some Agronomic Parameters, Nitrogen, Phosphorous and Potassium Uptake by Amaranthus viridis in Derived Savannah of Southwest Nigeria. J Hortic 3

3. Matheri F, Nyamai D, Ngugi MP, Runo S, Njuguna JK, et al. (2016) Phenotyping of Selected Kenyan Passiflora edulis Varieties and Their Hybrids Based on Quantitative Morpho-agronomic Traits. J Hortic 3.

4. Zhang L, Ren J, Li T, Wang A, Tan D (2016) De novo Transcriptome Sequencing of Cold-treated Kentucky Bluegrass (Poa pratensis) and Analysis of the Genes Involved in Cold Tolerance. J Hortic 3.

5. Yuan H, Jiang Z, Zhang L, Yue P, Wang A (2016) Characterization of the Pear (Pyrus ussuriensis) Actin-depolymerizing Factor PuADF During Fruit Ripening. J Hortic 3.

6. Maier RM, Williamson RC (2016) Evaluation of Kaolin Clay as an Alternative Management Tactic for Japanese beetle Feeding Damage in Grape Vineyards. J Hortic 3(3): 1-6.

7. Aryal D (2016) Effect of Nitrogen and Azotobacter in Growth and Development of Chilly. J Hortic 3: 185.

This work is licensed under Creative Commons Attribution 4.0 License DOI: 10.19080/JOJHA.2018.01.555578 